\title{
Government Organizational Restructuring of West Borneo Province Based on Government Regulation Number 18 Year 2016 on Regional Apparatus
}

\author{
Amri Pratama \\ Universitas Muhammadiyah Yogyakarta \\ Yogyakarta, Indonesia \\ amrip@rocketmail.com; mutiarin@yahoo.com
}

\author{
Dyah Mutiarin \\ Universitas Muhammadiyah Yogyakarta \\ Yogyakarta, Indonesia
}

\begin{abstract}
This study aims to describe regional apparatus organizational restructuring based on Government Regulation Number 18 Year 2016 regarding Regional Apparatus and factors considered by the government of West Borneo province. This study used organization theories and regional governance concept as well as bureaucracy concept to enrich this study. Based on qualitative research method and interactive model of data analysis technique, this study discovers that the government organizational restructuring of West Borneo province is conducted based on top down and inward looking. The result of the study also shows that the factor being considered the most is government authority owned by province government, while the factor being considered the least is public participation.
\end{abstract}

Keywords- Organizational Restructuring; Regional Government; West Borneo Province.

\section{INTRODUCTION}

Regional government organizational restructuring or rearrangement of regional apparatus organization is a very important policy particularly related to the need of improving public service quality. The demand on the availability of qualified public service to the community requires the regional government to make changes in many sectors, one of them is in organizational restructuring which is oriented on the need of public service. The organizational restructuring is not conducted in the paradigm of fulfilling the need of internal bureaucracy anymore, but it has to be based on the need of public service for the community.

According to Warsito Utomo (2005) the condition of government organization in Indonesia still shows that bureaucracy is nevertheless considered as the activity which leads to the occurrence of bureaucratism or bureaucracy pathology which has reputation of slow, complicated, big, sluggish, inefficient, routine, stiff, unperceptive, arrogant,

having complicated procedure, emphasizing on formality, and many others which cause or make the government or organization activities become ineffective, inefficient, unresponsive and not economical. The property of protuberant or big is one of the prominent features of the government organizational structure in which the organization is formed with a tendency of being expanded or enlarged in order to fulfill the organization's internal need or interest.
The condition of bureaucratic organization in Indonesia is elaborated further by Prasojo (2006) who states that one of the important factors of bureaucratic problem is a big organizational structure which makes it slow and inefficient. The condition of big organizational structure creates work culture which is slow, ineffective and inefficient in implementing its main duty and function for providing public service. Moreover, the certain condition will reduce the responsivity level of regional government towards the need and preference of its citizens.

Related to previous elaboration, there are some interesting facts about the regional government organizational structure problems recently. One of them is stated by the Deputy for Institutional Affairs, Ministry of Administrative Reform and Bureaucracy Reform in a focus group discussion in Bangka in 2012. It is stated the portray of regional government institution in Indonesia recently is big and unprofessional, prioritized on structural approach instead of functional, clash of authorities/overlap, disharmony or seizure of authority either vertical or horizontal, and the lack of strong commitment to rightsizing in which all of them lead to profligate bureaucracy, inefficient and unaccountable.

Further consequences of the Indonesian government which is bureaucratic is that internally, it leads to regional finance corruption, profligacy of kinds of sources, collation with businessmen, nepotism particularly in the employees' recruitment and promotion. Besides that, externally, the government organization does not have the ability to respond the occurring environmental changes, especially to respond the community demand for qualified public service.

Therefore, a regional government organizational restructuring has to be done in a new paradigm or framework of thinking, in which the formation of governmental organization should be based on external consideration instead of internal. The regional government organizational restructuring should be conducted based on characteristics, potency and local excellence as well as an analysis on the need of public services for the community. Regional government organizational restructuring is not merely implementing government internal bureaucracy anymore.

Law Number 23 Year 2014 on Regional Government brings significant changes towards the formation of regional apparatus, with the principle of proper function and rightsizing 
based on work load which is appropriate with the real condition in each region. It is in accordance with the principles of local apparatus organizational structure which are rational, proportional, effective and efficient.

As the follow up from the Law Number 23 Year 2014, the central government issued Government Regulation Number 18 Year 2016 on Regional Apparatus as the guidance for the Regional Government to arrange the organizational structure of its local apparatus.

Since there are complex problems and challenges related to local government organization; therefore, a study about local government organizational restructuring has a high urgency. Hence, to conduct a comprehensive study, various theories and concepts which are relevant to be used are organization theories, concept of local government and concept of local government authorities, and certain perspectives which are peculiarly related to regional bureaucracy comprehension.

According to Robbins (2006:4) an organization is a social entity which is coordinated consciously, with a limitation that is relatively identifiable, which works based on relatively continuous to achieve common goals or a group of goals. Furthermore, Robbins (2006:77) defines organizational restructure as a process of redesigning or rearranging the existing bureaucracy structure when a dynamic change occurs in both internal and external environment then the bureaucracy has to adapt that dynamic changes so that it can develop. The adaptation towards the dynamic occurrence makes the bureaucracy has to perform in accordance with the existing reality. Restructuring or rearrangement organizational bureaucracy is basically an activity to arrange bureaucratic organization unit which will be given certain field of work, duty or function.

Miftah Thoha (2002) differentiates public organization with other organizations based on the following aspects:

1. The services provided by the public organization are considered more important than private organization. It is related the interests to all community levels in which if they are given to other parties it is feared that they will not work well.

2. The services provided by the public organization is more monopoly or semi monopoly, it means that it is relatively difficult to be shared with other organizations.

3. In providing public services, the public organization and its administrator, based on constitutions and other regulations, provide the color of legality. Therefore, the services will be "slow" in adjusting themselves with various changes.

4. The public organization in serving the community is not based on the market price like a company.

5. The efforts of public organization will be felt directly by the community; therefore, its implementation should be fair, proportional, impartial, clean and prioritize the public interests.

Related to the organizational structure, Mintzberg (1993:153) describes the intended five main foundations as follows:
1. The Strategic Apex, is part of the organization which functions as the responsible part to ensure the succeed of the organization in achieving its goals;

2. The Middle Line, is part of the organization which is in charge to help translating the policies of top management which then delivered to the operational unit to be followed up;

3. The Techno structure, is part of the organization which functions to analyses the leader's policies by issuing various kinds of guidelines or certain standards which should be noticed by all regional apparatus / each user;

4. The Supporting Staff, is part of the organization which basically provides supports for the overall duty of regional apparatus; and

5. The Operating Core, is part of organization which functions to implement the main duty of the organization related to the direct services to the community.

According to Deddy Supriady et al (2001: 158) regional apparatus is formed based on the following considerations:

1. Government authority owned by the region

2. Characteristics, potency and region's need

3. Capability of regional finance

4. Availability of apparatus resources

5. Development of cooperation pattern among regions and/or with the third party

Discussing about the government's roles cannot neglect the trend in public management development. In the beginning, the Old Public Management (OPM) concept was very dominating the practice of governance implementation in almost all countries. One of the basic characters of OPM is that the government institution itself that provides all public services using a very closed system (does not open for participation) through the process of planning, organizing, providing staff, directing, coordinating, reporting and budgeting (Lynn: 2006). The concept and practice of OPM then shifted by New Public Management (NPM) in 1980s era. Some principles of NPM which differentiates it form OPL is steering rather than rowing, empowerment instead of service, competition in providing service, result oriented, service oriented on customers, collecting revenue instead of spending, anticipating instead of healing, decentralization and participation, market oriented (Osborne and Plastrik, 1997).

Nowadays, the paradigm of public management has shifted from OPM and NPM to New Public Service (NPS). According to Denhart and Denhart (2007) there are some basic characters in NPS which differentiate it from OPM and NPM. First, service is on citizens not on the customer. Second, focusing on the value of achieving public interests. Third, focusing on the value of citizenship instead of entrepreneurship. Fourth, think strategically and act democratically. Fifth, establishing accountability mechanism. Sixth, giving services and not controlling, And seventh, giving value on the service to the citizens and not on productivity.

Based on New Public Service paradigm, regional government organizational restructuring which is implemented 
is by considering local community need and the real condition of that region so that it is expected that it can achieve the goal to create a regional apparatus organization which is close to the people, concerns to the effort of improving public service for the community, and together with the community is able to solve the problems faced.

Regional government organizational restructuring has been conducted by the government of West Borneo province. Based on the Regional Regulation of West Borneo Number 8 Year 2016 on Formation and Structure of Local Apparatus of West Borneo, which consist of I Regional Secretariat: I Regional Legislative Council/DPRD Secretariat; I Inspectorate; I Civil Service Police Unit; 22 departments; and 7 agencies.

West Borneo Province is one of the provinces in Indonesia which has a special characteristic, in which its region has a directly adjacent with the neighboring country, Malaysia. There are at least five districts which directly adjacent with Malaysia, those are Bengkayang, Sambas, Sanggau, Sintang and Kapuas districts. Besides that, characteristic, West Borneo province also has important needs especially related to education, health and infrastructure.

In terms of public service, the obedience of West Borneo government towards the service standard has not optimum yet. Based on the assessment conducted by the Ombudsman as the representative of West Borneo Province in 2015, the government of West Borneo Province is categorized in yellow zone with its score is 75.11 . While in 2016 the government of West Borneo province still categorized in yellow zone but the score is decreasing which is 59.81. The assessment, even though has not assess the service performance in details but focuses more on the obedience towards service standards, the neglect towards service standard may potentially result in bad public service quality.

Based the previous elaboration, organizational restructuring implemented with a new paradigm is extremely needed, in which the restructuring is not only conducted for internal interest of regional bureaucracy but it is oriented more on characteristics, need and regional potency as well as the improvement of public service quality for the community.

Therefore, it emerges a question which is very important to study on how the government organizational restructuring of West Borneo province based on the Government Regulation Number 18 Year 2016 regarding regional apparatus and what factors being considered in the implementation of that organizational restructuring.

\section{RESEARCH METHOD}

This study used qualitative method. This method was used to describe the result of the study profoundly. The data analysis technique used was the interactive model developed by Miles and Huberman (1994) which consist of data collection, data reduction, data display, and conclusions drawing. The data used were primary and secondary data. The primary data were gained through in-depth interview with the informants. While the secondary data were obtained by tracking documents from the legislations and policies issued or enacted by the government of West Borneo which are relevant to the regional apparatus organization restructuring. The informants in this study was determined using purposive sampling technique who consisted of representative of regional government, Regional Legislative Council, Academics and Ombudsman. The informants from the representative of Regional Government was Organization Bureau of the Regional Secretariat of West Borneo province government, the representative of regional Legislative Council of West Borneo province was special committee of Regional Apparatus Organizational Structure/pansus SOPD team of West Borneo province, the academic representative was the lecturer of Social Science and Politics Science Faculty of Graduate Program of Universitas Tanjungpura Pontianak and the representative of Ombudsman was the Ombudsman commissioner representative of West Borneo

\section{RESUlT AND DisCUSSION}

\section{A. Regional Apparatus Organizational Restructuring Process of West Borneo Province}

The changes on Law Number 32 Year 2004 on regional government by issuing Law Number 23 Year 2014 on regional government, bring significantly a lot of changes especially related to the authority owned by the government, provincial government and regency/municipal government. The changes of authority also affect the requirement to suit regional apparatus organization in each province government and district/municipal government by referring to Government Regulation Number 18 Year 2016 on regional apparatus.

The policy from the central government then implemented by the government of Wet Borneo province by conducting organizational restructuring of its regional apparatus by referring to the new legislations which are Law Number 23 Year 2014 on regional government and Government Regulation Number 18 of 2016.

The Government of West Borneo province immediately made adjustments towards the new legislation followed by the formation of executive team led by regional secretariat organization bureau of West Borneo Province to implement the restructuring of regional apparatus of West Borneo province.

The process of the government organizational restructuring of West Borneo province is conducted by having discussion in forms of coordination meetings and technical institution, either with Regional Work Unit or with district/municipal government. The coordination with the central government and conducting the government affair mapping which becomes the authority of the government of West Borneo province uses general variable for $20 \%$ (twenty percent) and technical variable for $80 \%$ (eighty percent). The criteria of general variables are determined based on the local characteristics which consist of the indicators on the total 
population, area size, and the amount of regional revenue and expenditure budget. While the criteria of technical variables are determined based on main duty load on each government affair which becomes the authority of province region and supporting function of government affair.

The result of government affair on the government of West Borneo province: there are 40 government affairs which are mapped, and the result is that there are 22 government affairs categorized as big work load and can be formed as a department or agency of A type (the score of mapping result > 800) which are as follows:

TABle 1. Result of AfFair Mapping A TyPe

\begin{tabular}{clc}
\hline No & \multicolumn{1}{c}{ Affair } & Score \\
\hline $\mathbf{1}$ & Health & 880 \\
\hline $\mathbf{2}$ & Public Works and Spatial Planning & 825 \\
\hline $\mathbf{3}$ & Peace and Public Order and Community Protection & 1760 \\
\hline $\mathbf{4}$ & Social & 924 \\
\hline $\mathbf{5}$ & Women's Empowerment and Child Protection & 858 \\
\hline $\mathbf{6}$ & Living environment & 814 \\
\hline $\mathbf{7}$ & Population and Family Planning Control & 814 \\
\hline $\mathbf{8}$ & Transportation & 823 \\
\hline $\mathbf{9}$ & Cooperatives, Small and Medium Enterprises & 803 \\
\hline $\mathbf{1 0}$ & Youth and Sports & 1034 \\
\hline $\mathbf{1 1}$ & Marine and Fisheries & 834 \\
\hline $\mathbf{1 2}$ & Tourism & 1001 \\
\hline $\mathbf{1 3}$ & Agriculture & 999 \\
\hline $\mathbf{1 4}$ & Forestry & 1034 \\
\hline $\mathbf{1 5}$ & Mineral Resource Energy & 845 \\
\hline $\mathbf{1 6}$ & Transmigration & 902 \\
\hline $\mathbf{1 7}$ & Industry & 902 \\
\hline $\mathbf{1 8}$ & the regional Secretariat & 946 \\
\hline $\mathbf{1 9}$ & Inspectorate & 825 \\
\hline $\mathbf{2 0}$ & Planning & 836 \\
\hline $\mathbf{2 1}$ & Finance & 880 \\
\hline $\mathbf{2 2}$ & Research and development & 880 \\
\hline & & a. Source: Organizational Bureau of Regional Secretariat of West \\
\hline & & \\
\hline
\end{tabular}

Then, there are 14 government affairs which are categorized as medium workload and they can be formed as department or agency of $\mathrm{B}$ type (the score of mapping result $600-800)$ as follows:

TABle 2. Result OF AfFAIR MAPPING B TYPE

\begin{tabular}{clc}
\hline No & \multicolumn{1}{c}{ Affair } & Score \\
\hline $\mathbf{1}$ & Education & 616 \\
\hline $\mathbf{2}$ & Housing and Settlement Area & 645 \\
\hline $\mathbf{3}$ & Labor & 638 \\
\hline $\mathbf{4}$ & Food & 792 \\
\hline $\mathbf{5}$ & Population Administration and Civil Registration & 792 \\
\hline $\mathbf{6}$ & Community and Village Empowerment & 714 \\
\hline $\mathbf{7}$ & Communication and Informatics & 656 \\
\hline $\mathbf{8}$ & Capital investment & 770 \\
\hline $\mathbf{9}$ & Library & 772 \\
\hline $\mathbf{1 0}$ & Filing & 660 \\
\hline $\mathbf{1 1}$ & Trading & 653 \\
\hline $\mathbf{1 2}$ & Secretariat of Regional Legislative Council/DPRD & 700 \\
\hline $\mathbf{1 3}$ & Staffing & 616 \\
\hline $\mathbf{1 4}$ & education and training & 616 \\
\hline & $\quad$ b. Source: Organizational Bureau of Regional Secretariat of West Borneo Province
\end{tabular}

Further, there are 4 government affairs which are categorized as low workload and they can be formed as department or agency of $\mathrm{C}$ type (the score of mapping score $<600)$ as follows:

TABle 3. Result of AfFair Mapping C Type

\begin{tabular}{clcc}
\hline No & & Affair & Score \\
\hline $\mathbf{1}$ & Land & 154 \\
\hline $\mathbf{2}$ & Statistics & 154 \\
\hline $\mathbf{3}$ & Encryption & 332 \\
\hline $\mathbf{4}$ & Culture & 506 \\
\hline & \multicolumn{2}{c}{ c. Source: Organizational Bureau of Regional Secretariat of West Borneo Province }
\end{tabular}

The mapping result becomes one of the foundations in forming regional apparatus organization of West Borneo Province which is arranged in a regional regulation and discussed together among the Province Government and Regional Legislative Council of West Borneo Province. Then, the result of the shared discussion is enacted in in Regional Regulation of West Borneo Province Number 8 of 2016 in Formation and Structure of Regional Apparatus of West Borneo Province. The final stage of Government organizational restructuring of West Borneo Province is conducting consultation with the Ministry of Internal Affairs to get an approval.

\section{B. The Result of Government Organizational Restructuring of West Borneo Province}

Regional government organizational restructuring has been conducted by the government of West Borneo province with the enactment of the Regional Regulation of West Borneo Number 8 of 2016 on Formation and Structure of Local Apparatus of West Borneo. Based on that Regional Regulation the regional apparatus organization structure consists of I Regional Secretariat: I Regional Legislative Council/DPRD Secretariat; I Inspectorate; I Civil Service Police Unit; 22 departments; and 7 agencies, which are:

1) Regional Secretariat

2) Regional Legislative Council/DPRD Secretariat

3) Inspectorate

4) The Civil Service Police Unit

5) Local Agency (Implementing Government Affairs)

- Department of Education and Culture

- Health Office

- Department of Public Works and Spatial Planning

- Department of Public Housing, Settlement and Environment Area

- Social Service

- Department of Manpower and Transmigration

- Department of Women Empowerment and Child Protection

- Department of Food, Animal Husbandry and Animal Health

- Department of Population and Civil Registration

- Community and Village Empowerment Office

- Department of Transportation

- Department of Communications and Informatics

- Department of Cooperatives, Small and Medium Enterprises

- Department of Investment and One Stop Integrated Service 
- Youth, Sports and Tourism Department

- Library and Filing Service

- Department of Marine and Fisheries

- Department of Agriculture of Food Crops and Horticulture

- Department of Plantation

- Forestry Service

- Department of Energy and Mineral Resources

- Department of Industry and Trade

6) Agency (Elements Supporting Governmental Affairs)

- Regional Development Planning Agency

- Regional Financial Management and Revenue Board

- Regional Personnel Agency

- Human Resource Development Agency

- Agency for Research and Development

- Liaison Agency

- Regional Disaster Management Agency

The organizational restructuring conducted by the government of West Borneo Province by referring to the Government Regulation Number 18 Year 2016 on Regional Apparatus resulted in the size of regional apparatus organization which is smaller compared to the previous regional apparatus organizations.

\section{Consideration Factors}

\section{Government Authority Owned by The Region}

Law Number 32 Year 2004 regarding Regional Government has been revoked and replaced by the new Law which is Law Number 23 Year 2014. One of the most important changes of that law is about the distribution of government affairs between the Central Government, Provincial Government, and Regency / Municipality Government.

The amendment is at least existed in details in the area of government affairs which is divided among the Central Government, Provincial Government and Regency / City Government which are previously stipulated in the attachment of Government Regulation Number 38 of 2007 is now improved for its regulations to be part of the attachment of Law Number 23 Year 2014. Therefore, the division of affairs which has been enacted in Law No. 23 of 2014 is expected to be unimpaired / excluded by other sectoral laws.

On the aspect of government affairs classification there are changes in Law Number 32 Year 2004 which are divided into affairs that become the authority of regional government (obligatory affairs and optional affairs) as well as residual government affairs. While based on the Law Number 32 Year 2004 the classification of government affairs is divided into Absolute government affairs which is the government affairs that is completely become the authorization of central government. Congruent government affairs are the government affairs which are divided between the central government, provincial and regency/municipal. General government affairs are the government affairs that become the authority of the president as the head of government.

On the aspect of congruent government affairs division, there are changes between the Law Number 32 year 2004 and Law Number 23 Year 2014 in which in the Law Number 32 Year 2004 the criteria were only regulated in general such as externality, accountability, and efficiency by paying attention on the harmony of relations among the government structures. While the Law Number 23 Year 2014 has arranged more obviously related the criteria of each government affair, in which on central government which its authority is government affair that the location is cross province or cross country; the government affairs that the users are across province or cross country; the government affairs that the benefits or negative impacts are cross province or cross country; the government affairs which is the use of resources is more efficient when it is carried out by the central government; and/or the government affairs which roles are strategic for national interest. On the provincial government, the authority criteria are the government affairs located cross region of regency/municipal; the government affairs that the users are cross region of regency/municipal; the government affairs that the benefits or negative impacts are cross region of regency/municipal; the government affairs which is the use of resources is more efficient when it is carried out by the province area. Meanwhile, the authority criteria are the government affairs located in the regency/municipal; the government affairs that the users are in the regency/municipal; the government affairs that the benefits or negative impacts are only in the regency/municipal; the government affairs which is the use of resources is more efficient when it is carried out by the regency/municipal area.

In conducting organizational restructuring, the government of West Borneo province is indeed considering the government authority factor owned by the region. The team works based on the prevailing laws and regulations which are Law Number 23 Year 2014 regarding Regional Government, Government Regulation Number 18 Year 2016 regarding Regional Apparatus and various instructions and decree from the ministry of internal affair particularly Number 188/3774/SJ dated 11 October 2016 on guidelines for local regulatory approval on regional apparatus. Based on the legislation then the formation of regional apparatus can be conducted only if there is a government affair which becomes the authority of provincial government, as a result the regional apparatus organizational restructuring in West Borneo Province is really consider the government authority owned by the region.

\section{Characteristics, Potentials, and Regional Needs}

Geographically, West Borneo province is located in the western part of the island of Borneo, or in between the lines $2^{\circ} 08^{\prime} \mathrm{N}$ and $3^{\circ} 05^{\prime} \mathrm{S}$ and between $108^{\circ} 0$ ' $\mathrm{E}$ and $114^{\circ} 10^{\prime} \mathrm{E}$. It is adjacent to Sarawak (East Malaysia) in its northern part. In its southern part, it borders Java Sea and Central Borneo, and it borders East Borneo its eastern part. Meanwhile, in its western 
part, it borders The Natuna Sea and The Karimata strait. Most areas of West Kalimantan are a low-lying land. This region stretches straight from north to south along more than $600 \mathrm{~km}$ and about $850 \mathrm{~km}$ from West to East. This geographical condition makes its five regencies namely Bengkayang, Sambas, Sanggau, Sintang and Kapuas Hulu directly border Malaysia.

Demographically, population becoming the object and subject of the development is dynamically connected with all aspects of the development. Population-related targets and policies are an integral part of the overall development in the fields of culture, economy, social, politics, defense and security. Bad management of the population dynamics will badly effect those aspects. The similar thing also happens in restructuring regional apparatus. If the demographic dimension is ignored, the regional apparatus restructure will not be optimal in providing services to the community. The population of West Borneo Province in 2015 based on data provided by the bureau of Population and Civil Registration of West Borneo Province totaled 5,323,985 million inhabitants.

$2,741,694$ inhabitants $(51.50 \%)$ of the total population of West Borneo are males, and 2,582,291 inhabitants (48.50\%) are females. The residents inhabit an area of 146,807 km2, and each kilometer per square is inhabited by 36 people. With a population density of 36 people / Km2, West Borneo Province is categorized as sparsely populated. This condition is certainly less profitable in order to accelerate the development of the region especially related to the management of natural resource with its all potentials and diversities.

The population distribution of West Borneo is uneven across regencies / cities, sub-districts, villages, or between coastal areas or urban and rural areas. For example, the coastal areas covering Sambas regency, Bengkayang regency, Mempawah regency, Ketapang regency, Kayong Utara regency, Kubu Raya regency and Singkawang city are inhabited by almost $50 \%$ of the total population of West Borneo with the density of 41 persons / Km2. In contrast, seven other regencies (excluding beaches) other than Pontianak city have the population density that are relatively rare (19 people / Km2). Kapuas Hulu regency with an area of $29,842 \mathrm{~km} 2$ or about $20.33 \%$ of the total area of West Borneo is only occupied by 8 people / Km2. Meanwhile, the city of Pontianak which is less than one percent $(107.80 \mathrm{~km} 2)$ is inhabited by 5,548 people / Km2. Uneven distribution of the population can also be an obstacle in carrying out the service function and improving the welfare given to the community.

In addition to its characteristics, West Borneo Province also has diverse potentials. It is viewed from the economic aspect using the data of Gross Regional Domestic Product (GRDP) growth to measure potential sectors developed in West Borneo Province in 2014-2015 based on the constant price of 2000.

Of all 17 business sectors, agriculture, forestry and fishery sectors became the largest contributors from 2014 to 2015 followed by the manufacturing sector, the big and retail trading sectors as well as the auto and motorcycle repair sectors. These sectors are very potential to be developed continuously.

In addition to the characteristics and potentials, regional needs become another factor to consider in restructuring the organizations of the regional apparatus. Each region has its own needs. In West Borneo Province, some emerging needs are education, health and infrastructure. The data on education of West Borneo Province show that in 2015 the enrollment rate for primary school was $99.27 \%$, and the enrollment rate for junior high school / MTs-Islamic junior high school was 91.91\%. Meanwhile, the enrollment rate for senior high school/ MA-Islamic high school was $66.83 \%$. The data also show the teacher ratio for the students of elementary school / MI-Islamic elementary was 1:18, and the ratio of teachers for junior high school students was 1:17.

The health needs in West Borneo Province is also very important. The data on health of West Borneo province in 2015 show that the ratio of community health center per person was 1: 19.327, the ratio of hospital per person was 1: 110,494 , the ratio of bed availability per person was $1: 906,5$, the ratio of general practitioners per person was $1: 8,274$, the dentist ratio per person was 1: 40. 309. The ratio of specialist doctors per person was 1: 19.984. The ratio of nurses per person was 1: 677 . The midwife ratio per person was 1: 1,565. Meanwhile, the availability of community health center per sub-district was 1:33. Those data indicate that the health infrastructure needs to be improved to ease the public visit if the residents want to get treatment. In addition, the role of medical personnel in providing services to the community also becomes an important requirement in improving the quality of public health.

The regional infrastructure in West Borneo also needs to be the priority. The need for regional infrastructure cannot be separated from its function and role to the development of the region to direct and form spatial structure, fulfill the needs of the region, trigger the region growth as well as to strengthen the regions. The infrastructure condition of West Borneo province in the ratio of road length per vehicle number ranged between 1: 80,42 up to 1: 141,90 in 2015 .

Furthermore, in the aspect of road condition, the $1.940 \mathrm{~km}$ state road was in good condition, while the other $177.08 \mathrm{~km}$ was in bad condition. Then, the $1.342,52 \mathrm{~km}$ provincial road was in good condition, and the other $313,49 \mathrm{~km}$ was in bad condition.

In restructuring the organizations of regional apparatus, the provincial government of West Borneo has considered the factors of characteristics, potentials and needs of the region. As written in the Law no.23/2014 about regional government and the government regulation no.18/2016 about regional apparatus, the classification of government affairs comprises of compulsory government affairs and optional government affairs. Compulsory government affairs are the government affairs conducted by all regions, while the optional 
government affairs are government affairs that must be conducted by the regions in accordance with their potentials.

The optional governmental affairs written in the Law no.23/2014 about regional government include marine and fishery affairs, tourism, agriculture, forestry, energy and mineral resources, commerce, industry and transmigration. The establishments of the services of marine and fishery, agriculture and horticulture, plantation, forestry, energy and mineral resources department, industry and commerce, labor and transmigration, youth, sports and tourism were the results of the government organizational restructuring of West Borneo Province. The establishment of those organizations are used to accommodate the factors of characteristics, potentials, and needs owned by West Borneo Province.

In detail, the establishment of the Plantation service in West Borneo Province was based on its large plantation sectors which are directly managed by the community as well as the private companies and SOEs that work on large-scale plantations with the realization of large plantation products.

In addition to the Plantation service, an independent Forest Service was also established by considering the characteristics, the potentials and the regional needs.

From the aspect of characteristics, the potentials and needs of regions, the management of border areas is the aspect that cannot be accommodated in the formation of regional apparatus organization. As described in the characteristic of the region, West Borneo Province is a border area. There are at least 5 districts directly adjacent to Malaysia. However, SKPD (regional government agencies) cannot be established to manage border areas in West Borneo because there is no authority to the provincial government.

As written in the Law no.23/2014 about regional government, the management of border areas becomes the authority of the central government, not the provincial government, so that a special SKPD dealing with the border area cannot be established. Then in the letter of the Minister of Home Affairs no.188/3774 / SJ dated on October 11 2016, the terms of the local regulatory approval on regional apparatus of points 1.g. submitted to support the coordination of development in the border areas of the country. In the border of provinces and regencies / border cities, secretariat of state border is formed directly attached in one working unit at the regional secretariat whose regulations are set up in the regulation of the head of the region about the organizational structure and regional apparatus working procedures. Therefore, based on the letter of the Minister of Home Affairs to the Provincial Government of West Borneo, the function in coordinating the border area development is attached to the regional secretariat government bureau.

\section{Regional Financial Capacity}

Regional financial capacity is an important factor to consider in restructuring the organizations of the regional government. The Regional Revenue and Expenditure Budget (APBD) of West Borneo province in 2016 was Rp.
1.923.033.474.000, 00. This budget resulted from locallygenerated revenue totaled Rp. 1.923.033.474.000,00,balancing funds totaled Rp. 1.690.288.626.000,00, and other legitimate revenues totaled Rp. 958.161.400.000,00. The locallygenerated revenue portion was $42.07 \%$, the balancing funds portion was $36.97 \%$, and the portion of legitimate revenues were $20.96 \%$.

Self-supporting ability in financial is one important criteria to know the regional ability to regulate and take care their government. The financial independence factor is an essential factor to measure the level of regional capability in the implementation of autonomy. The development of PAD in its APBD structure is used to measure the region's financial capacity. With the PAD proportion of $42.07 \%$ in APBD, West Borneo Provincial Government was still classified as a regional government with medium self-supporting capability in 2016 .

Regional financial capacity becomes an important factor to consider in restructuring the government organizations of West Borneo Province. Moreover, in the government regulation no.18/2016 about regional apparatus, regional financial capacity becomes one general indicator in mapping the affairs of structuring the regional apparatus.

Based on the regional financial capacity, some government affairs are merged, such as:

- The Education and Culture Service is a combination of educational affairs and cultural affairs.

- The People's Housing, Settlement and Environment Service is a combination of housing and settlement affairs and environmental affairs.

- The labor and transmigration Service is a combination of labor affairs and transmigration affairs.

- The Food, Livestock and Animal Health Service is a combination of food affairs, the agriculture affairs, subaffairs of animal husbandry and animal health.

- The Communications and Informatics Service is a combination of communications and informatics affairs, as well as statistical and coding affairs.

- The Youth, Sports and Tourism Service is a joint affair of youth and sports with tourism affairs.

- The Library and Filing Service is a combination of library affairs with archival affairs.

- The Industry and Trade Service is a combination of industrial affairs with trade affairs.

Merging some government affairs in a regional apparatus organization is aimed to reduce over budget. By considering the financial aspect both spending, income, and benefits resulted by the formed organizations, the overbudget can be reduced without reducing the quality of their basic tasks and functions.

\section{The Availability of Apparatus Resources}

The availability of apparatus resources is one factor needed to be considered in restructuring the regional apparatus organizations because the availability of apparatus sources 
significantly determines the organizations of the regional government to conduct their basic tasks and functions. Without it, the regional apparatus organization may not do their tasks and functions well.

Generally, the availability of apparatus resources in West Borneo province is adequate. Quantitatively in 2016, there were 6.178 apparatus in West Borneo Province. This number is a condition where the provincial government of West Borneo has not received government civil servants from the regencies /cities as a result of the change of government authority from the districts / cities government to the provincial government.

One of the consequences of governmental authority change as regulated in the Law no.23/2014 about regional government is the government of West Borneo Province to receive the transfer of personnel or civil servants from the regencies/ cities government. At least 5,846 personnel or civil servants from the regencies / cities of West Borneo consisting of high school / vocational school teachers, forest workers and labor inspectors were transferred. Their civil service status became the civil servants of West Borneo Provincial Government. As a result, the number of civil servants of West Borneo became 11,664 .

In the implementation of regional apparatus organization restructure of West Borneo Province, it does not take into account the availability of apparatus resources since it is not included in the mapping indicator of affairs regulated in the government regulation no.18/2016 about regional apparatus. Moreover, the availability of apparatus resources is also considered to have little effect on institutional formation.

Taking a little account of the availability of apparatus resources, the result of the West Borneo government organizations restructure indicates that 10,271 civil servants, or $88.06 \%$ were in the regional apparatus organizations performing mandatory government affairs and the other 1,393 civil servants or $11.94 \%$ were in the regional apparatus organizations handling the optional government affairs.

From the position's aspect, when compared to the composition of civil servant position in West Borneo Government before and after the organization restructure, there was a reduction of 3 echelon II officials, and 15 echelons III officials. However, there was an addition of 6 echelon IV officials.

The addition of 6 echelon IV officials was caused by the change of the regulation. In the old regional apparatus organization referring to the government regulation no.41/2007, the technical regional institution at the level of echelon IV only consisted of 2 subfields. Whereas, the new organization of regional apparatus referring to government regulation no.18/2016, the regional technical institutions at the level of echelon IV consists of 3 subfields.

In detail, based on the new regional apparatus organization in West Borneo Provincial Government, there is 1 echelon IB official, 49 echelons II officials consisting of 37 echelons II A officials and 12 echelon II B officials. Then, there are 258 echelons III officials consisting of 253 echelons III A officials and 5 echelon III B officials, 745 echelons IV officials consisting of 729 echelons IV A officials and 16 echelon IV B officials as well as 10,611 officials with specific functional positions and general functional functions.

The positive implication of taking little consideration of the availability of apparatus resources in restructuring the organizations of West Borneo Provincial Government is to limit the official's power occupying important positions in the West Kalimantan Provincial Government for a long period of time. However, this decision also has negative impacts for it makes the composition and distribution of civil servants are uneven with the needs of each organization of the formed regional apparatus.

\section{The Development of Cooperation Patterns Between Regions and with Third Parties}

One factor needs to be considered in restructuring government organizations is the development of cooperation patterns between regions and with third parties. In the provincial government of West Borneo, the pattern of cooperation has been going well with the central government and regencies / cities government as well as with the third parties/ private sectors.

In 2014 to 2016, West Borneo undertook at least 67 cooperation agreements with various parties, both with the central government, regencies / cities governments as well as with private parties. In detail, there were 9 corporations with the regencies/ cities government, 2 corporations with provincial government, 14 corporations with central government, and 42 corporations with third/private parties.

In restructuring the organizations of West Borneo provincial governance, the development of cooperation pattern between regions and with third parties is not really considered, so the formed pattern of cooperation is the vertical cooperation not the multilateral one. The pattern of coordination between units of local government organizations is done vertically. In this case, the regional secretary plays a very vital role as the coordinator of all parts, agencies, and offices in the regional government environment. The existing coordination system remains in vertical pattern.

The limitation to develop multilateral cooperation pattern is caused by the pattern of categorization written in the government regulation no.8/2016 about the regional apparatus. It has been arranged in detail about the categorization of government affairs, so the formation of regional apparatus organizations cannot go beyond the arranged categorization. Article 18 of paragraph 4 mentioned that the incorporation of government affairs in 1 provincial regional service is based on the governmental affairs categorization with these criteria: a. closeness of the characteristics of government affairs; and $b$. the interrelationship between the administration of government affairs. 
With that pattern of coordination, the lateral pattern of coordination among organizational units become unfulfilled. The horizontal pattern of coordination among organizational units cannot be achieved as well because each working unit of regional apparatus is oriented upwards.

This affects the attempt in creating the characteristics of collaborative organizational structures and the attempt in creating a multi-lateral coordination pattern in which vertical and horizontal and lateral relationships are not yet achieved.

\section{Public Participation}

Public participation is one of the important factors to be considered in implementing the organizational restructuring. The need for public services and other public aspirations should be well understood and embodied in the structure of the established regional apparatus organizations.

The Law no.10/2004 about the establishment of legislation in article of 53 clearly sets out the participation of communities in the establishment of legislation including Perda-regional regulations. As the subject to receive all forms of services provided by the regional apparatus, the public also has the right to participate in the drafting process. However, the regional apparatus organizations restructure in West Borneo have not considered the factor of public participation.

Little consideration of public participation in restructuring regional apparatus organization is a step that should not be done. The existing paradigm understands the process of restructuring of regional apparatus organization as internal affairs of regional government organization only assigned by central government to the regions. The process is not understood as a public process namely as a way to solve public service affairs to the citizens. Community components substantially are not involved in discussion of changes that must be made concerning organizational structuring the regional apparatus organizations

Moreover, in some assessments conducted by the Ombudsman representative of West Borneo in 2015, West Borneo was into the yellow zone category with the value of 75.11. Meanwhile in 2016, West Borneo was still included in the category of yellow zone with the score of 59.81. Although the assessment had not fully evaluated the public service performance, more aspects of pursuance toward the service standards were assessed. Neglecting service standards can potentially lead to poor service quality.

Neglecting service standards will also result in maladministration and corrupt behavior of the apparatus, and the long neglect of service standards may result in the decline of credibility or public trust in the government. From the community report, the Ombudsman of West Borneo also noted that from 2012 to 2016, there were 35 public services of the West Borneo Government disappointing the community.

Looking at various assessments and public reports about the public services provided by the government, the government of West Borneo ideally should involve public participation to improve the quality of public services in West Borneo when restructuring its organizations.

\section{CONCLUSION}

The organizations restructure of the government of West Borneo was done in a top down and inward looking. It refers to the government regulation no.18/2016 about regional apparatus which has set up the operation very technically and made the regional government along with DPRD- regional house of representative having no room to innovate in accordance with the characteristics, requirements and potentials of the region as well as the needs of public service for the society.

Furthermore, the most important factor to consider in implementing the government organization restructure of West Borneo is the authority of government owned by the provincial government. Meanwhile, the least considered factor is public participation.

In designing the new organizational structure, the formed teams both in the executive and the legislative mostly consider the authority factor of the government owned by the provincial government as a result of the central government provisions. The formation of regional apparatus organizations can only be done if there are government affairs which become the authority of the provincial government and do not have much dialogue with stakeholders about public service strategic issues because the process of restructuring the regional apparatus organizations was simply understood as an internal affairs of regional government organizations as a coordinating institution to carry out the government affairs assigned by the central government to the regions. That process has not been understood as a public process that is as a way to solve public service affairs to the public.

\section{REFERENCES}

[1] Bratakusumah, Deddy Supriady, dan Dadang Solihin. Otonomi Penyelenggaraaan Pemerintahan Daerah. Gramedia Pustaka Utama. Jakarta. 2001.

[2] Denhardt, Janet V., and Denhardt. Robert B. The New Public Service: Serving, not Steering, M.E. Sharpe. New York. 2003.

[3] Gifford \& Elizabeth Pinchot. The End of Bureaucracy \& The Rise of the Intelligent Organization. Berrett - Koehler Publishers, San Francisco. 1993.

[4] Hellriegel, Don, and J. W. Slocum Jr. Organizational Behavior. South Western. 2001.

[5] Kalimantan Barat Dalam Angka Tahun 2016

[6] Lynn, L.E., Jr. Public Management: Old and New. New York. Routlage. 2006.

[7] Miles, M.B. dan A.M. Huberman. Qualitatif Data Analysis. Californis : Sage Publication inc. 1994.

[8] Mintzberg, Henry. Structure in Five Designing Effective Organizations. Prentice-Hall, Inc. New Jersey. 1993.

[9] Osborne David and Ted Gaebler. Reinventing Government, How the Entrepreneurial Spirit is Transforming the Public Sector. 1992.

[10] Prasojo, Eko, "Restrukturisasi Organisasi Perangkat Pemerintah Daerah: Sebuah Refleksi Teoritis dan Praktis terhadap PP 8 Tahun 2003," CLGI-Newsletter, edisi IV, 2003.

[11] Robbins, Stephen. Organization Theory: Structure, design and application, terjemahan Yusuf Udaya, Teori Organisasi: Struktur, desain dan aplikasi. Jakarta: LP3ES. 1994.

[12] Thoha, Miftah. Perilaku Organisasi. Raja Grafindo Persada. Jakarta. 2002. 
[13] Utomo, W. Administrasi Publik Indonesia di Era Demokrasi Lokal. Yogyakarta: UGM. 2005

[14] Undang-Undang Nomor 23 Tahun 2014 tentang Pemerintahan Daerah.

[15] Peraturan Pemerintah Nomor 18 Tahun 2016 tentang Perangkat Daerah.

[16] Peraturan Daerah Provinsi Kalimantan Barat Nomor 8 Tahun 2016 Tentang Pembentukan dan Susunan Perangkat Daerah Provinsi Kalimantan Barat 